\author{
Poznań Studies in Contemporary Linguistics 46(3), 2010, pp. 313-330 \\ (C) School of English, Adam Mickiewicz University, Poznań, Poland \\ doi:10.2478/v10010-010-0017-3
}

\title{
VALUES OF THE 2004 E.U. ENLARGEMENT IN MEDIA DISCOURSE
}

\author{
MACIEJ KIELAR \\ Adam Mickiewicz University, Poznań \\ maciek@ifa.amu.edu.pl
}

\begin{abstract}
Values and ideology are assumed to be discursive phenomena. Therefore, the aim of the analysis in the present paper is to present linguistic markers of values that are responsible for organisation of various spheres of life, and the same time, for the shape of ideology of the 2004 EU enlargement as it has been presented in the print media.

To exemplify these assumptions, a Press release corpus consisting of some 30,000 words was gathered. It encompasses articles published between 15 April and 7 May 2004 which represent such journalistic genres as press note, report, commentary, report with elements of commentary and coverage. In the course of the study, expressions pointing to particular spheres of life were identified and analysed as referring to particular values of the E.U.
\end{abstract}

KEYWORDS: Discourse; values; European Union; mass media; journalism.

\section{Introduction}

Researchers into the history of Europe and the EU associate the 20th century's appearance of the idea of integration with Churchill's speech of 1946 when he suggested creating of "a kind of United States of Europe" (Jones 1996: 6-8; Pinder 2001: 4-5) that was to unite in co-operation only the continental countries, especially to reconcile France and Germany. However, as Pinder (2001: 1-4) marks, the EU as a process began in 1952 together with launching the European Coal and Steel Community which was intended to bind these industries of France and Germany under supranational control and "materially" prevent a war. Italy, Belgium, Luxembourg and the Netherlands were the other four countries founding the ECSC, as they noticed the possibility of maintaining peace in Europe thanks to binding Germany within the Community. It becomes clear that maintaining peace and security was the main political motive from the beginning. The organisation comprised the principles of solving conflicts and of co-operation, 
which can be seen in the preamble to the Treaty of Paris of 1951, which is pointed out in the quotation presented by Archer (1990: 4):

\begin{abstract}
Resolved to substitute for historic rivalries a fusion of the essential interests; to establish, by creating an economic community, the foundation of a broad and independent community among the peoples long divided by bloody conflicts; and to lay the basis of institutions capable of giving direction to their future common destiny.
\end{abstract}

It might be inferred that peaceful co-operation would not be possible without the economic benefits offered by the new organisation. Submitting coal and steel production to supranational control, accompanied by the free movement of these goods helped members of the ECSC in better management leading to economic profit. Guided by these results among others, politicians founded the European Economic Community (EEC) and European Atomic Energy Community (Euratom) in 1958. This was a step further in the process of economic integration as the EEC treaty facilitated the opening of the common market, the approximation of member states' economies, the common commercial policy towards other countries, and the free movement of goods, labour and services. The treaty on the European Union, reforming the structures of the EEC came into force in 1993, and from then on we talk of the EU.

With economy as an integrating factor accompanied by the promotion of democracy, freedom, and the protection of human rights, the pace of the process of European integration was accelerated considerably due to destruction of the "Iron Curtain" in 1989, Germany's reunification in 1990 and the fact that Soviet Union dissolved in 1991. Highlighting the importance of the 2004 EU enlargement, Wojtaszczyk (2006: 14-16) indicates that it was the biggest enlargement that took place in the EU history. Ten countries, eight of which belonged to the former Soviet block, and two Mediterranean countries joined the EU.

As it has already been mentioned, the EU is seen as an ongoing process. The historical and social significance of changes and happenings of the recent years related to the EU enlargement, its institutional problems and urgent needs for reforms, especially the EU Constitution, and ratification of the Lisbon Treaty have gained recognition of their importance in the realm of discursive studies as their discussion in the EU institutions or media that reach Europeans is done by means of language use. Musolff (2004) presents an analysis and discussion of metaphors that are used in the press discourse with reference to the EU and related matters. Oberhuber (et. al. 2005) discusses the press coverage of the EU constitutional debate. They focus on investigation of such issues as choice of agency and metaphors, as well as on the way the Brussels Summit has been presented in the press of several European countries. Krzyżanowski and Oberhuber (2007) devote the whole book to the issue of institutional debate over the EU constitution and give some insider view on EU institutional practices.

In the present paper, bearing in mind the historical importance of the $2004 \mathrm{EU}$ enlargement, the focus is on Irish and British press coverage of the event. The aim of 
the analysis is to highlight the principles of the EU which are responsible for creating and maintaining the EU ideology underlying all its operations that were referred to by the journalists. For the purpose of this analysis, the principles mentioned in treaties are referred to as values. Their presence, as well as the frequency of mentioning, may in turn signify the political stance of the newspaper, its attitude towards the EU enlargement, as well as towards the EU on the whole.

\section{Pragmatics of axiological concepts}

In this section, the focus is on presenting theoretical assumptions that are vital for the current investigation. I start with a presentation of some of Krzeszowski's (1997: 1416) ideas. The first one says that the most general and widely used scale of valuation is the "good - bad" scale. Furthermore, valuation cannot be separated from categorisation. This results in an assumption that if valuation is an aspect of categorisation, and categorisations are directly manifested in language, then the link between axiology and linguistics becomes clearly visible. Bartmiński (2003: 59-63) agrees with Krzeszowski and says that valuation takes place as early as the stage of the conceptualisation of reality. What is more, Bartmiński (2003: 75) signals that values, being present as early as that, help in the recognition and categorisation of reality. Therefore, they direct the process of conceptualisation. Values determine the function of basic notions and, at the level of discourse, the intention of communication which is connected to values adapted by the sender of a message.

However, it seems necessary to realise what are the possible ways in which values and valuations are manifested in language. Puzynina (1992: 111-115) states that they may be expressed by the systemic properties of language or may depend on the textual use of particular lexical elements. It must be said that it may be rather difficult to distinguish between these two types. As the author suggests, if the valuation performed by means of words such as "good - bad", "pretty-ugly", etc., is quite obvious, expressing valuation by means of syntax, morphology, phonetics, or even paralinguistic features is not so. Therefore, particular syntactic constructions, in which certain verbs are used, may include the speaker's/writer's valuation of an action. Particular types of complex sentences may also be of a valuating character. In the case of morphology, the valuating potential is restricted to flectional languages. The phonetic means of value expression encompass all the phenomena to which we globally refer as intonation. Finally, the language of gestures, which is characteristic for particular cultures, may also be involved in the expression of values.

To summarise Puzynina's stance, once again Bartmiński (2003: 59-60) shall be mentioned, as he reports that values enter the system of language and can be extracted as language facts. In other words, values stand apart from language and happen to be expressed on the levels either of code or spoken/written texts. It should be remembered that the means of valuation which appear on the level of code are the scarcest, because 
they are conventionalised elements of the language system. Many more possibilities of valuation in language are "offered" by the text level, as it is always supported by context. Therefore, as Bartmiński says, according to Puzynina, an axiologicaly-minded linguist should investigate the systemic means of expressing values. However, a linguistic investigation may go beyond this assumption and may also focus on the identification of values that are referred to in texts.

Therefore, as mentioned in previous papers (Kielar 2010, in press), in order to conduct a coherent analysis of values and valuation expressed in language, it is Puzynina's theory that seems to fit a discursive analysis better. This view can be supported by van Dijk's (1998: 43, 74-77, 314-318) ideas and, what is more, can direct one towards the method of analysis. First, van Dijk points to the fact that values belong to the sphere of culture, which is more general than the sphere of ideology. Therefore, values enter the construction of ideologies from a higher level and govern them through their evaluative dimension. Second, people acquire, share and change ideologies in the course of social interaction such as language use. These views are repeated by Verschueren (1999: 238) who points that ideology can be seen as a conglomerate of commonsense, and basic, often normative beliefs that are manifested in discourse. As Fairclough (1989: 2; 84-85) says, the notion of commonsense is crucial to an understanding of the link between ideology and language, firstly, because commonsense assumptions as ideological and manifested in all kinds of the social behaviour, and secondly, because language is the most common form of social behaviour based on commonsense assumptions. Relating the above presented ideas hint at the use of Critical Discourse Analysis (henceforth CDA) as the investigative perspective. According to indications made by Kress and Hodge (1979: 4-9), Fairclough (1989: 17-26, 1995: 131), Fowler (1991: 4), Schiffrin (1994: 39-40), Wodak (1995: 204-207, 2000: 187-192, 2004: 105-122), CDA assumes the perception of discourse both as a social practice such as the contextually determined language use and as a collection of socially constructed values.

As has been mentioned, values govern the social construction of ideologies, which in turn are responsible for organising various spheres of human life. For the purpose of this paper, the term "domain of life" designates a particular field of human activity. Therefore, mentioning different "domains of life" and further stressing different values within these domains may suggest the ideological stance of the one producing the message.

2. Abstracting values from British and Irish press discourse

\subsection{The data}

Similarly to other papers (Kielar 2007: 87-89, 2010: 50-51, in press), the corpus prepared for the purposes of the present study of values and valuation in the journalistic discourse regarding the ideology of the enlargement of the European Union consists of 
some 30,000 words. It comprises texts selected from UK and Irish national daily newspapers. The corpus is summarised in Table 1.

Table 1. The list of genres in the selected newspapers.

\begin{tabular}{|c|c|c|c|c|c|c|c|}
\hline \multirow[b]{2}{*}{ Title } & \multicolumn{5}{|c|}{ Genre } & \multirow{2}{*}{ Total } & \multirow{2}{*}{ Words } \\
\hline & P. N. & $\mathrm{R}$. & $\mathrm{C}$. & R.-C. & Cov. & & \\
\hline B. T. & $1(25 \%)$ & $2(50 \%)$ & $1(25 \%)$ & - & - & 4 & 1718 \\
\hline D. M. & $1(33 \%)$ & - & - & $2(66 \%)$ & - & 3 & 1718 \\
\hline D. T. & $1(20 \%)$ & $2(40 \%)$ & $1(20 \%)$ & - & $1(20 \%)$ & 5 & 2623 \\
\hline I. & - & $1(20 \%)$ & - & $3(60 \%)$ & $1(20 \%)$ & 5 & 4902 \\
\hline S. T. & - & - & - & $2(100 \%)$ & - & 2 & 3158 \\
\hline G. & - & - & $2(66 \%)$ & $1(33 \%)$ & - & 3 & 3853 \\
\hline T. & - & - & $1(25 \%)$ & - & $3(75 \%)$ & 4 & 3870 \\
\hline I. I. & $1(33 \%)$ & - & $1(33 \%)$ & $1(33 \%)$ & - & 3 & 1817 \\
\hline S. I. I. & - & - & $2(100 \%)$ & - & - & 2 & 1568 \\
\hline I. T. & - & - & $3(33 \%)$ & $3(33 \%)$ & $3(33 \%)$ & 9 & 6722 \\
\hline
\end{tabular}

Abbreviations:

(1) Newspapers titles: D.M. - Daily Mail; D.T. - Daily Telegraph; I - Independent; S.T. - Sunday Times; G. - The Guardian; T. - The Times; B.T. - Belfast Telegraph; I.I. - Irish Independent; S.I.I. - Sunday Irish Independent; I.T. - The Irish Times.

(2) Genres: P.N. - Press note; R. - Report; C. - Commentary; R.-C. - Report with elements of commentary; Cov. - Coverage.

It needs to be recognised that each of the ten titles has its own "favoured" genres which are exploited more often than others. It has to be remembered that the UK, Northern Ireland and the Republic of Ireland are different political states having different degrees of autonomy and occupying a very small geographical area; however, in all of these states English is the official language. This selection of the newspapers should enable the researcher to indicate whether there are any differences in the perception, or rather presentation, of a particular political and/or historical event in these states whose histories have been tightly interwoven for many centuries.

As regards the assumed political affiliation, one may notice that these newspapers represent all political agendas present in British and Irish politics. The Daily Telegraph may be seen as an example of a conservative newspaper and The Guardian as a representative of the left wing. The Independent, The Irish Independent and Sunday Irish Independent might be seen as liberal, while The Times, The Sunday Times and The Irish Times might be perceived as representing the centre of the political ground. This assignment of particular titles to given political agendas was based on inferences made after reading articles and comparing the ideas included in them to statements expressed by the political leaders with reference to the enlargement of the EU. 
Regarding the quality of the publication, one may notice that these newspapers represent the mid-market and quality newspapers with the exception of The Daily Mirror, which is the only representative of a so-called tabloid publication. The Sun is the bestrecognised title of this type; however, the length of the articles featured and the quality of language in this title are not sufficient to subject them to linguistic analysis. In the course of the data collection, we have noticed that the average article published in The Sun is composed of a huge title, short editorial and a photo, while the body of the article is reduced to just a few sentences. This in turn would make it difficult, if not impossible, to conduct the desired analysis. If the focus were just on the editorials or the titles of articles, the data could be successfully included in the study.

All of these texts have been published and have since been stored in archives on the web pages of the given title. The search through the web archives of these newspapers was conducted in December 2005 and January 2006. As a result of this, forty articles which belong to five different journalistic genres were selected.

These genres may be labelled: the press note, report, commentary, report with elements of commentary, and coverage. It is important to notice here that, as McQuail (2005: 370), Bauer (2004: 143-145) and Mrozowski (2001: 323) say, the idea of journalistic genre is constantly evolving. Hence, genre distinction is presented as a continuum rather than as the set of clearly identifiable classes. In other words, the genre of the Press does not posses a set of easily identifiable distinctive features characteristic of a particular genre and not of any other. It is also suggested that it is mainly the impression of the reader which enables any such divisions. In accordance with these assumptions, the distinction presented here could be characterised as impressionistic. The distribution and frequency of use of a particular genre could be characterised as follows. Commentary is the genre most frequently used. It has 11 attestations in 7 out of 10 titles. Report with elements of commentary is the second most often used genre, as it appears 12 times in 6 out of 10 newspapers. Then, there is the coverage which could be recognised 8 times in 4 titles. The press note appears 4 times in 4 titles and report has 5 attestations in 5 titles out of 10 .

\subsection{Presenting examples of vital values of the $2004 \mathrm{EU}$ enlargement}

Following Śpiewak's (1982: 23) principle, values can be analysed with reference to a concrete material. The focus of this paper is restricted to journalistic texts whose general theme is the EU enlargement. In the course of preparation to the analysis proper, sub-themes have been recognised. The process of enlargement is a very complex procedure involving the specification of the relations that link the member states within the EU after the expansion. In the accession documents, these relations are precisely described with reference to various spheres which may generally be characterised as social, political, or economic, etc. Within these spheres, the functioning of the EU and its citizens is precisely formulated. 
In the texts analysed from the ten selected newspapers, we come across seven such domains of life. It was decided to treat history and politics as a one, as the demarcation between politics and history is rather difficult to establish. It may be suggested that politics is in fact "the making of history", so what today is called politics, tomorrow will be called history. The domain called "migration" also poses certain problems. There is no doubt that it is a process affecting the social life; however, for different reasons, such as political or economic, it was decided to treat it as separate. The following five domains posed no such problems in delimitating: economy, society, background information, ecology, and education. Therefore, these seven domains of life are exemplified by their leading value according to which they seem to be organised in the journalistic discourse. Some other values are also present in these domains; however, their presence seems to be less significant. In cases of such domains as "politics/history" and "economy", it was decided to present two examples of values, that is, the leading one and one that follows it in terms of frequency of appearance.

\subsubsection{Values in the domain of politics and history}

The first EU value to which we shall refer is "democracy and peace", as it is the value that determines this domain. Four extracts whose main topic is politics and history, and whose organising values are democracy and peace, will be presented.

\section{Democracy and peace}

Fifty years after World War Two, modern Europe is still evolving but the rapprochement that has developed between states that were once at war should be an example to the wider world. Enlargement will undoubtedly produce new challenges but the concept of a Europe finally at peace with itself must be cherished (Belfast Telegraph, 1 May 2004).

In example (1), the key words or expressions introducing the value are the verb "evolving", the noun "rapprochement", and the noun phrase "Europe finally at peace". The verb signifies the peaceful process of change without rapid or violent events. The noun indicates relations based on friendship and mutual co-operation and the noun phrase "Europe finally at peace: requires no further explanation, as the "peace" is here selfexplanatory, and serves both as value and the value bearer.

\section{Common EU policy}

Enlargement will surely force the pace of European reform in time if for no other reason that the Union will grind to a halt if it does not. And enlargement will do something else. It will provide a new dynamic for the long-term future 
of the Union. Those 10 joining today, it should not be forgotten, are only the start. Others will soon follow, including, we hope, Turkey. If only politicians could raise their eyes above the immediate they would see a shape of Europe we can still barely envisage. (Independent, 1 May 2004)

The value of common policy entered the organisation during of its development and evolution into what we know now as the European Union. Therefore, it might be said that this value determines the political sphere of life which could be compared to "history in the making". The key valuating expressions in (2) are "force the pace of the European reform" and "a new dynamic for the long-term future". In the former, the "force" indicates that before enlargement European reforms were not conducted in a satisfactory manner, and only now will they be carried out properly. Hence, the verb "force" introduces a positive valuation. The latter is the noun "reform." This suggests the adjustment to the contemporary situation for the purpose of better functioning. It seems that this noun will always denote positive values. Finally, there is the phrase "a new dynamic for the long-term future". Here, the most important valuating words are "dynamic" and "long-term future". By means of the former, the author suggests the further development of the EU, and in the latter indicates that this provides proper functioning of the union.

\subsubsection{Values in the domain of the economy}

As has already been said, every domain of life is organised according to some particular value. In the case of the economy, we might suspect that this value would be that of the free market. The other EU value, in terms of frequency, that could be seen here is freedom of movement.

Free market

The biggest expansion in Europe's history is only two days away when some relatively poor and struggling countries from central and eastern Europe will be ushered into what's been known as a "rich man's club". In our countdown to enlargement, we look at what this will mean to Britain - and what our new neighbours will need to know. (Daily Mail, 29 April 2004)

In example (3), one can find such valuating phrases as "relatively poor and struggling countries", "will be ushered" and "a rich man's club". The first of these expressions negatively values the economic potential of the countries that are to become new members of the EU. This negative valuation is stressed by the passive verb phrase which values the new countries as somehow not fully able to operate within the realms of the European free market. The phrase "rich man's club" values the EU as the organisation 
restricted to those who can afford it by virtue of bringing in capital, or rather economic power.

\section{Freedom of movement}

Poland, with a population of 39 million, is the largest of the 10 new EU members. The Germans and French have long argued that cheap Polish labour would flood Western Europe as soon as Poland entered the EU. (Daily Telegraph, 28 April 2004)

The value of the free market economy is closely related to the value of the freedom of movement. It is based on the assumption that every citizen has the right to settle and work in the country one chooses to live. This in turn has an impact on the market. The unemployment rate in one part of the EU might be falling, while in another it is rising. The migration of the labour force may also influence wages in a given economic sphere.

In (4), one may see a description of a situation where two countries of the "old" union try to protect their national economies. The valuation expressions are the verb phrase "long argued", the adjective "cheap", and another verb, "flood." The first of these indicates that this must have been a problem for the EU for some time, and the verb "argue" values the situation as a fierce discussion over the principles or the principle differences. The adjective "cheap" indicates that there are discrepancies in the case of wages between the "old" and "new" EU, which is a crucial factor for a calculation of the costs of work. The whole situation is negatively valued by the use of the verb "flood" which suggests a violent, uncontrolled, and massive influx of people from the new member states, which would have a disastrous effect on the home economy.

\subsubsection{Values in the domain of migration}

The domain of life known as migration is solely governed by the EU value of the freedom of movement.

\section{Freedom of movement}

Amid much alarmist talk about a flood of new arrivals in Britain from the eastern bloc, a sense of proportion must be maintained. The reality is that with its birth rate falling, the UK urgently needs new workers. (Belfast Telegraph, 1 May 2004).

In quotation (5), the most noticeable valuating word is "flood." It has already appeared in the context of the domain of life of economy, where it signified a rapid and uncon- 
trolled influx of labour. Here, as a valuating word, it is used in a similar way. However, this time the focus of the latter part of the extract is directed towards the social domain, which is marked by a negatively loaded subordinate clause "birth rate is falling". Crucial here is the verb "falling" which indicates a negative valuation. As to the perception of the value of freedom in this example, it is valued positively. This is indicated in the phrase "urgently needs new workers". The adverb "urgently" suggests desperation for "fresh blood" which may help in sustaining the ageing society. At this point it becomes clearly visible that various domains of human activity are interconnected.

\subsubsection{Values in the domain of society}

The social domain of life signifies a rather broad sphere of human activity. However, as in the case of any typology it is possible to indicate the most important feature which functions as the basis for assigning a given entity to the particular type. Such an approach results in the fact that we have identified four values of the EU which govern the social domain.

The first of EU values that we shall address is the value of democracy and peace. Example (6) refers to ethnic problems, either to those that may happen within the new enlarged EU, or to those that the EU actually prevents from escalation.

\section{Democracy and peace}

Even beyond the borders of today's new Europe, the EU's benign influence is calming ethnic tensions in Macedonia and Bosnia Herzegovina as the lure of membership forces governments to behave responsibly. (Independent, 1 May 2004)

In example (6), the positive valuation of the EU acting according to the value of democracy and peace is expressed in the clause "the EU's benign influence is calming the ethnic tensions". The adjective "benign" signifies the actions that are performed according to the democratic procedures that seek to "calm the ethnic tensions", or in other words, maintain peace in the Balkans. Extract (6) exemplifies the close relation between democracy and peace, where acting upon the former may influence the state governed by latter.

\subsubsection{Values in the domain of background information}

As we have already stated, the domain of life which we called "background information" consists of pieces of information that make the issue of EU enlargement more familiar to readers. It is not devoted to any particular topic, but rather to a whole array of 
themes that are superficially treated; hence, it is impossible to pinpoint one value that would determine this domain. In the course of the analysis of the data, we came across such EU values referred to by authors as democracy and peace, free market economy, common EU policy, and nature.

\section{Democracy and peace}

The new enlarged union will be one of $450 \mathrm{~m}$ people and 20 official languages, stretching from the Atlantic to the borders of Russia across three time zones and deep into the territory of the old Soviet Union.

This is the EU as the world's greatest peace project, healing not just the divisions of the Second World War but of the Cold War too. (Irish Independent, 1 May 2004)

In (7), the valuation referring to the EU is expressed by means of the noun phrase "the world's greatest peace project" and the adjective "healing". As this is the domain named "background information", the author introduces a positive valuation of the EU as an organisation that keeps the peace. Here, the adjective "greatest" would rather signify the quality of actions taken by the EU, while the peace project would point to the very value of peace. The adjective "healing" indicates that the EU after the enlargement will be responsible not only for keeping the already established peace but also for spreading it further to new countries that were forced to remain outside democratic European institutions. The adjective "healing" is in itself a positively valuating word that indicates recovering from some health difficulties. In such a case, one might say that the author uses a medical metaphor to describe the sate Europe was experiencing on the verge of the enlargement in 2004.

\subsubsection{Values in the domain of ecology}

To exemplify the value labelled "nature", we shall present a passage taken from one article published in The Belfast Telegraph. It is important to mention that this article is the only one in the corpus that was completely devoted to environmental issues.

\section{Nature}

A report by Traffic Europe reveals that current differences between wildlife trade controls in existing and new EU states have allowed traders to legally import species that have been banned in the EU for years. (Belfast Telegraph, 27 April 2004)

In (8), the journalist bases the valuation on the noun "differences", the denotation of which is neutral. However, in the context of the above extract, it gains a negative col- 
ouring, as it is used to indicate problems the new member states, or rather their regulations, might cause in respect to the trade in wild animals. In this way, the author values the "old" EU regulations as better in securing animal rights in than the "new" EU countries.

\subsubsection{Values in the domain of education}

Education is the final domain of life that we found in the course of the analysis. It was attested only twice in the corpus. Apart from this scarcity, what is even more peculiar about this domain is the EU value that has been detected. In texts on EU enlargement, journalists present the value of freedom of movement as responsible for governing this domain.

\section{Freedom of movement}

British universities are expected to benefit from the enlargement of the European Union, and one institution in particular is hoping for a big boost - not just by increasing its student numbers, but also from the general opening up of Eastern Europe. It is University College London's School of Slavonic and East European Studies (SSEES), founded in 1915 as a centre for the study of the new nation states then emerging from the First World War, and now about to take on a new lease of life as a hub for learning about the states that made up the former Soviet Union. (Independent, 1 May 2004)

Extract (9) seems to indicate the emergence of an interest in the new countries that is the result of the possibility to travel around the European Union without significant restrictions. This is indicated in the phrase "the general opening up of the Eastern Europe" where the positive valuation is expressed by the noun "opening up". This very noun suggests the situation in which anyone wishing to may travel to or from a given country. This is presented as a positive feature of the EU enlargement.

With example (9) we shall finish the presentation and discussion of particular examples of the valuating expressions, and shall move to the next section, where all of the results of the analysis will summarised and discussed.

\section{Discussion and conclusions}

As may be seen in Table 2, politics and history is the domain of life that is most frequently referred to, not only by virtue of the fact that there are 75 attestations found in 140 analysed examples, but also because references to this domain are present in every newspaper. Such distribution should be of no surprise, as the outcome of the EU 
enlargement of 2004 was that for the first time countries that used to belong to two opposing blocs were brought together in a single political alliance. Such an action must have historical consequences for the continent.

Table 2. The domains of life in the content of the selected newspapers.

\begin{tabular}{|c|c|c|c|c|c|c|c|c|c|c|c|}
\hline \multirow{2}{*}{ Domains } & \multicolumn{11}{|c|}{ Title } \\
\hline & B.T. & D.M. & D.T. & I. & S.T. & G. & T. & I.I. & S.I.I. & I.T. & Total \\
\hline$\overline{\text { Politics/history }}$ & 4 & 7 & 6 & 12 & 5 & 12 & 7 & 2 & 5 & 15 & 75 \\
\hline Economy & 7 & 1 & 4 & 1 & 3 & - & - & 5 & - & 6 & 27 \\
\hline Migration & 1 & 2 & - & - & 3 & 1 & 2 & 2 & - & - & 11 \\
\hline Society & 1 & - & 2 & 5 & - & 2 & - & - & - & 1 & 11 \\
\hline $\begin{array}{l}\text { Background } \\
\text { information }\end{array}$ & 4 & - & 1 & 2 & - & 1 & - & 1 & - & - & 9 \\
\hline Ecology & 5 & - & - & - & - & - & - & - & - & - & 5 \\
\hline Education & - & - & 1 & 1 & - & - & - & - & - & - & 2 \\
\hline
\end{tabular}

The second domain in terms of representation is economy. There are 27 examples referring to this domain; however, this time three newspapers, The Guardian, The Times, and The Sunday Irish Independent did not address domain. Such a situation is to some extant predictable, as the EU from its very beginnings as the ECSC was designed to facilitate the economic cooperation of the six countries. Migration, which is third on our list with 11 instances, also stems from the original assumptions of the ECSC that sanction the free movement of people, labour, and capital within the boundaries of the community. In this case, six of the ten newspapers made reference to this issue. The issue of migration is closely connected to that of society, or the social sphere of life. With 11 hits, it comes fourth in terms frequency because it was mentioned in five out of the ten newspapers. However, for the sake of the current study, the social domain refers to matters that stem from the idea of the solidarity of the member states within the community. The so-called "background information" was written about in 9 cases, also in five newspapers. There are also the domains of ecology, with five examples coming from one article which was published in The Belfast Telegraph, and education which was mentioned twice, once in Daily Mirror and once in The Independent.

It might be said on the basis of the analysed corpus of journalistic texts on the enlargement of the EU that the event was presented as of political and historical significance rather than as of any other. Looking at Table 2, one may also notice that particular newspapers favour only some particular domains of life. The most varied interest can be seen in the case of The Belfast Telegraph, in which six out the of seven spheres are mentioned, while the approximate average number of domains discussed in a single newspaper is three. Those are politics and history, economy and one of the following: migration, society, or background information. 
If we focus on the ideology of the EU and EU enlargement, we may search through texts for markers of particular values that would characterise the institution and its actions. Therefore, some further specification is necessary in order to focus our attention on matters closely connected to these issues. In this area, we decided to delimit the spheres of human activity which are referred to as the domains of life. Correlating the characteristics of types of values with the domains of life mentioned by the journalists should help in recognising the differences in specificity. Looking at the specific domains of life related to the subject of EU enlargement, one may notice that they only characterise different modes of the EU's existence. Hence, with reference to this particular subject journalists focused on the vital values.

Here, one might ask what the values are and how to determine them. The answer can be found in the history of the organisation. In historical sources, we can find the basic assumptions that gave rise to the ECSC, and led to its further transformations into the EEC, and finally into the EU. In brief, they can be specified as maintaining peace, promoting democracy, freedom of movement, free market economy, common decision making, solidarity of members, protection of the environment and legal standards. These entities, in turn, may be perceived not only as value bearers but rather as values that govern the EU and every enlargement that has taken place in history. Here it seems justified that these values are positive absolute vital values according to which the EU is organised and operates.

In Table 3, particular vital values of the EU are correlated with domains of life. What can be seen almost instantly is the fact that in almost all of the cases a given vital value refers to a particular sphere of life which is organised according to this value.

Table 3. Vital EU values and domains of life.

\begin{tabular}{|c|c|c|c|c|c|c|c|}
\hline \multirow[b]{2}{*}{ Domains of life } & \multicolumn{7}{|c|}{ Vital values of the EU } \\
\hline & $\begin{array}{c}\text { Demo- } \\
\text { cracy } \\
\text { and peace }\end{array}$ & $\begin{array}{c}\text { Free } \\
\text { move- } \\
\text { ment }\end{array}$ & $\begin{array}{c}\text { Free } \\
\text { market }\end{array}$ & $\begin{array}{l}\text { Common } \\
\text { EU policy }\end{array}$ & Solidarity & Nature & Law \\
\hline$\overline{\text { Politics/history }}$ & 55 & 3 & - & 15 & 1 & - & 1 \\
\hline Economy & - & 5 & 16 & 1 & 5 & - & - \\
\hline Migration & - & 11 & - & - & - & - & - \\
\hline Social & 5 & 2 & 1 & - & 2 & - & 1 \\
\hline $\begin{array}{l}\text { Background } \\
\text { information }\end{array}$ & 4 & - & 2 & 2 & - & 1 & - \\
\hline Ecology & - & - & - & - & - & 5 & - \\
\hline Education & - & 2 & - & - & - & - & - \\
\hline
\end{tabular}

For the purpose of the analysis, it was decided to treat peace and democracy as one value as these two mutually facilitate each other. Freedom of movement includes both the freedom to travel and settle, as well as the free movement of labour. The value of 
"free market" needs no further explanation. The "common EU policy" is the value that could be ascribed to all of the future actions of the EU in the realms of politics and economy, especially with reference to the future of the EU constitution. The value of solidarity indicates the co-operation and mutual help between the member states, especially in the field of economy. Within the EU, the natural environment may also be perceived as a value determining the domain of life known as ecology. Finally, legal standards (law) constitute a value in themselves. In a democratic and free market area, legal standards are crucial, as it is in accordance with them that all the actions should be conducted. However, as can be seen, journalists referred to these values only twice.

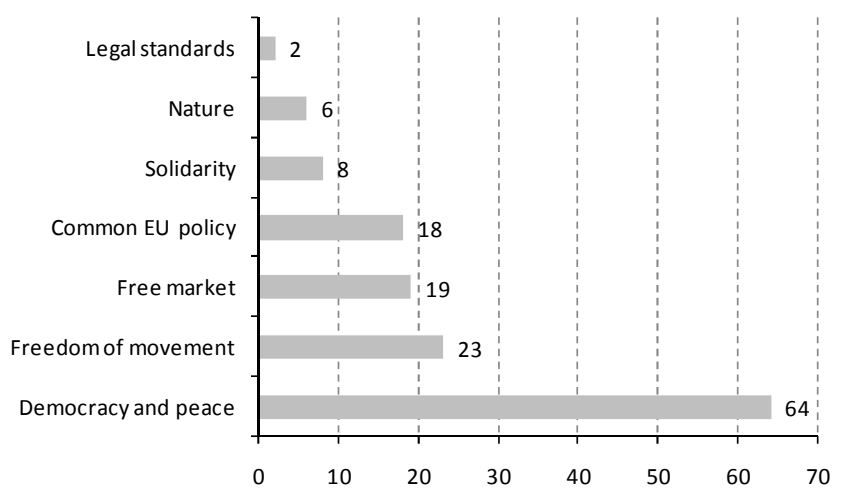

Figure 1. Vital values of the European Union.

In the course of the analysis, we have identified seven EU values that were referred to in texts. The value which is unquestionably the most frequently referred to is democracy and peace, with 64 attestations. This is followed by freedom of movement, free market economy and common EU policy. These three values were attested in texts almost the same number of times, which is: freedom of movement with 23 instances; free market economy with 19; and common EU policy with 18 . The last three are solidarity attested 8 times; nature, referred to 6 times; and legal standards, mentioned twice.

The numbers indicating the frequency of appearance in the texts might suggest that the EU enlargement was mainly valued and presented as a moment of history significant to the development of democracy and maintenance of peace, creating an area where people can travel and live wherever they want. Only later was this event perceived as economically significant. It is important to add that the value of democracy and peace is the only value that was indicated in all of the newspapers, and the value of the freedom of movement was referred to in nine out of the ten press titles subject to analysis. 
Table 4. Vital EU values in the ten selected newspapers.

\begin{tabular}{lccccccccccc}
\hline \multirow{2}{*}{ Values } & \multicolumn{10}{c}{ Title } \\
\cline { 2 - 11 } & B.T. & D.M. & D.T. & I. & S.T. & G. & T. & I.I. & S.I.I. & I.T. & Total \\
\hline D/P. & 5 & 3 & 3 & 16 & 5 & 8 & 6 & 2 & 5 & 11 & 64 \\
F.Mov. & 3 & 2 & 4 & 1 & 3 & 2 & 2 & 3 & - & 3 & 23 \\
F.Mar. & 5 & 1 & 4 & 1 & 3 & - & - & 3 & 1 & 1 & 19 \\
C.P. & - & 4 & 2 & 1 & - & 5 & - & 2 & - & 4 & 18 \\
S. & 2 & - & 1 & 1 & - & - & 1 & - & - & 3 & 8 \\
N. & 6 & - & - & - & - & - & - & - & - & - & 6 \\
L.S. & - & - & - & 1 & - & 1 & - & - & - & - & 2 \\
\hline
\end{tabular}

Abbreviations:

Values: D/P. - Democracy/peace; F.Mov. - Freedom of movement; F.Mar. - Free market; C.P. Common EU policy; S. - solidarity; N. - nature; L.S. - Legal standards.

This image of the enlargement of the EU is clearly visible in cases of such newspapers as The Independent, in which there are 16 references to the value of democracy and peace in the total of 21 valuating expressions, The Sunday Irish Independent (5/6), The Times (6/9), The Irish Times (11/22), and The Guardian (8/16). In the case of the rest of the newspapers, the frequency of reference to democracy and peace did not reach $50 \%$ of all their valuating expressions.

Going further, on the basis of such an analysis of press coverage, it seems rather difficult to indicate the political agenda of a given newspaper. This could be caused by the type of event that was subject to the press coverage. The process of the EU enlargement involved plenty of relations among different domains of life and values present in them. Therefore, it seems rather difficult to pinpoint the domain and value that could dominant for a given political ideology. What is more, it is a widely held belief that the $2004 \mathrm{EU}$ enlargement was the real end of a divided Europe; hence, it would not be wise to describe the process as negative. What one can arrive at seems to be just an image of the event that seems to be well balanced, neither EUro-sceptic, nor EUroenthusiastic, and avoiding political divisions into the Left, Centre, and Right, liberal or conservative.

\section{REFERENCES}

\section{Primary Sources}

The Belfast Telegraph $<$ http://www.belfasttelegraph.co.uk/search/index $>$ (Last accessed 19 Dec. 2005)

The Daily Mail <http://www.dailymail.co.uk/ pages/dmsearch> (Last accessed 19 Dec. 2005)

The Daily Telegraph <http://www.dailytelegraph.co.uk/search/index $>$ (Last accessed 6 Jan. 2006) 
The Guardian $<$ http://browse.guardian.co.uk/search $>$ (Last accessed 16 Dec. 2005)

The Independent $<\mathrm{http}: / / \mathrm{www}$. indeoendent.co.uk/index $>$ (Last accessed 16 Jan. 2006)

The Irish Independent < http://www.independent.ie/search/index.jsp $>$ (Last accessed 20 Jan. 2006)

The Irish Times < http://www.ireland.com/search> (Last accessed 16 Dec. 2005)

The Sunday Irish Independent $<$ http://www.independent.ie/search/index.jsp $>$ (Last accessed 20 Jan. 2006)

The Sunday Times $<$ http://www.timesonline.co.uk/tol/sitesearch $>$ (Last accessed 14 Dec. 2005)

The Times <http://www.timesonline.co.uk/tol/sitesearch> (Last accessed 14 Dec. 2005)

\section{Secondary sources}

Archer, C. 1990. Organizing Europe. The institutions of integration. London: Edward Arnold.

Bartmiński, J. 2003. "Miejsce wartości w językowym obrazie świata" [The role of values in the shaping of a linguistic world view]. In: Bartmiński, J. (ed.), Język w kręgu wartości [Language in the sphere of values]. Lublin: Wydawnictwo UMCS. 59-86.

Bauer, Z. 2004. "Gatunki dziennikarskie" [Journalistic genres]. In: Bauer, Z. and E. Chudziński (eds.), Dziennikarstwo $i$ świat mediów [Journalism and the world of media]. (3rd ed.) Kraków: Universitas. 143-173.

Fairclough, N. 1989. Language and power. London: Longman.

Fairclough, N. 1995. Critical discourse analysis: The critical study of language. London: Longman.

Fowler, R. 1991. Language in the news: Discourse and ideology in the press. London: Routledge.

Jones, R.A. 1996. The politics and economics of the European Union. An introductory text. Cheltenham: Edward Elgar.

Kielar, M. 2009. "Modality as a discursive marker of values and valuation." In: Wąsik, Z. and J. Zaprucki (eds.), Stowo jako wyraz duchowości człowieka [The word as an expression of human spirituality]. (Zeszyty Wydziału Humanistycznego III.) Jelenia Góra: Kolegium Karkonoskie w Jeleniej Górze. 85-98.

Kielar, M. 2010. "Values as discursive markers of national identity." In: Romedea, A.-G. (ed.), Cultural spaces and identities in (inter)action. (Interstudia 6/2010.) Bacău: Alma Mater. 4857.

Kielar, M. In press. "Transitivity as a marker of valuation in journalistic discourse.” In: Proceedings of PLM 2009.

Kress, G. and R. Hodge. 1979. Language as ideology. London: Routledge.

Krzeszowski, T.P. 1997. Angels and devils in hell. Elements of axiology in semantics. Warszawa: Energia.

Krzyżanowski, M. and F. Oberhuber. 2007. (Un)doing Europe. Discourses and practices of negotiating the EU constitution. Frankfurt am Main: Peter Lang.

Luke, A. 2001. "Ideology". In: Mesthire, R. (ed.), Concise encyclopedia of sociolinguistics. Amsterdam: Elsevier. 559-563.

McQuail, D. 2005. Mass communication theory. An introduction. (5th ed.) London: Sage.

Mrozowski, M. 2001. Media masowe: Władza, rozrywka i biznes [Mass media: Power, entertainment and business]. Warszawa: Oficyna Wydawnicza ASPRA-JR.

Musolff, A. 2004. Metaphor and political discouse. Analogical reasoning in debates about Europe. London: Palgrave MacMillan.

Oberhuber, F., C. Baerenreuter, M. Krzyżanowski, H. Schoenbauer and R. Wodak. 2005. "Debating the European constitution". Journal of Language and Politics 4(2). 227-271. 
Pinder, J. 2001. The European Union. A very short introduction. Oxford: Oxford University Press.

Puzynina, J. 1992. Język wartości [The language of values]. Warszawa: Państwowe Wydawnictwo Naukowe.

Schiffrin, D. 1994. Approaches to discourse. Oxford: Blackwell.

Schroeder, K.C. 2001 "Media language and communication". In: Mesthire, R. (ed.), Concise encyclopedia of sociolinguistics. Amsterdam: Elsevier. 246-255.

Śpiewak, A. 1982. "Wybrane problemy teorii wartości" [Selected issues in the theory of values]. In: Lipiec, J. (ed.), Człowiek i świat wartości [The man and the world of values]. Kraków: Krajowa Agencja Wydawnicza. 19-27.

Van Dijk, T.A. 1998. Ideology: A multidisciplinary approach. London: Sage.

Verschueren, J. 1999. Understanding pragmatics. London: Edward Arnold.

Wodak, R. 1995. "Critical linguistics and critical discourse analysis". In: Verschueren, J. and J.O. Östman (eds.), The handbook of pragmatics. Amsterdam: Benjamins. 204-210.

Wodak, R. 2000. "Recontextualization and the transformation of meanings: A critical discourse analysis of decision making in EU meetings about employment policies”. In: Sarangi, S. and M. Coulthard (eds.), Discourse and social life. Harlow: Pearson Education. 185-206.

Wodak, R. 2002. "Aspects of critical discourse analysis". Zeitschrift für Angewandte Linguistik 36. 5-31.

Wodak, R. and B. Busch. 2004. “Approaches to media texts”. In: Downing, J. (ed.), The Sage handbook of media studies. London: Sage. 105-122.

Wojtaszczyk, K.A. 2006. "Istota i formy integracji europejskiej" [The core and forms of Eurpoean integration]. In: Wojtaszczyk, K.A. (ed.), Integracja europejska: Wstep [European integration: An introduction]. Warszawa: Wydawnictwa Akademickie i Profesjonalne. 13-23.

\author{
Address correspondence to: \\ Maciej Kielar \\ School of English \\ Adam Mickiewicz University \\ Al. Niepodległości 4 \\ 61-874 Poznań \\ Poland \\ maciek@ifa.amu.edu.pl
}

